\title{
Selective Feeding and Microalgal Consumption Rates by Crown-Of-Thorns Seastar (Acanthaster cf. solaris) Larvae
}

\author{
Camille Mellin ${ }^{1,2,+, *}$, Claire Lugrin ${ }^{1,3, \dagger}{ }^{+}$, Ken Okaji $^{4}$, David S. Francis ${ }^{1,5}$ and Sven Uthicke ${ }^{1}$ \\ 1 Australian Institute of Marine Science PMB No 3, Townsville, QLD 4810, Australia; \\ claire.lugrin@epfl.ch (C.L.); d.francis@deakin.edu.au (D.S.F.); S.Uthicke@aims.gov.au (S.U.) \\ 2 The Environment Institute and School of Biological Sciences, The University of Adelaide, Adelaide, \\ SA 5005, Australia \\ 3 AgroParisTech, Paris 75005, France \\ 4 Coralquest Inc., 1-34-10 Asahicho, Atsugi 2430014, Japan; cab67820@pop06.odn.ne.jp \\ 5 Deakin University, Geelong, Australia, School of Life and Environmental Sciences, Warrnambool Campus, \\ Princes Hwy, Sherwood Park, PO Box 423, Warrnambool, VIC 3280, Australia \\ * Corresponding author: camille.mellin@adelaide.edu.au; Tel.: +61-08-8313-5432 \\ + These authors equally contributed to this work
}

Academic Editors: Morgan Pratchett and Michael Wink

Received: 24 November 2016; Accepted: 30 January 2017; Published: 7 February 2017

\begin{abstract}
Outbreaks of the crown-of-thorns seastar (CoTS) represent a major cause of coral loss on the Great Barrier Reef. Outbreaks can be explained by enhanced larval survival supported by higher phytoplankton availability after flood events, yet little is known about CoTS larvae feeding behaviour, in particular their potential for selective feeding. Here, single- and mixed-species feeding experiment were conducted on CoTS larvae using five algae (Phaeodactylum tricornutum, Pavlova lutheri, Tisochrysis lutea, Dunaliella sp. and Chaetoceros sp.) and two algal concentrations (1000 and 2500 algae $\cdot \mathrm{mL}^{-1}$ ). Cell counts using flow-cytometry at the beginning and end of each incubation experiment allowed us to calculate the filtration and ingestion rates of each species by CoTS larvae. In line with previous studies, CoTS larvae ingested more algae when the initial algal concentration was higher. We found evidence for the selective ingestion of some species (Chaetoceros sp., Dunaliella sp.) over others (P. lutheri, P. tricornutum). The preferred algal species had the highest energy content, suggesting that CoTS selectively ingested the most energetic algae. Ultimately, combining these results with spatio-temporal patterns in phytoplankton communities will help elucidate the role of larval feeding behaviour in determining the frequency and magnitude of CoTS outbreaks.
\end{abstract}

Keywords: electivity; feeding behaviour; filtration rate; Great Barrier Reef; phytoplankton

\section{Introduction}

Outbreaks of the crown-of-thorns seastar (Acanthaster cf. solaris, CoTS) represent a major threat for coral reefs and, in particular, for the Australian Great Barrier Reef (GBR). CoTS outbreaks are among the main causes of coral loss on the GBR since 1985 [1] and, unlike other causes, such as bleaching or cyclones, may be amenable to local or regional management. One of the most widely-accepted hypotheses explaining the increased frequency of CoTS outbreaks relates to the availability of phytoplankton, which is intimately linked to elevated terrestrial nutrient runoff [2-6]. Like most planktotrophic echinoderm larvae, CoTS larvae feed on nano-phytoplankton, and the larval development rate increases with food availability [7]; although high food concentrations may be detrimental to development and survival [8,9]. However, it is likely that phytoplankton diversity (or the dominance of certain species) is equally or more important than overall phytoplankton abundance with respect to larval development. 
While documented descriptions of the feeding mechanisms of CoTS in the early larval stages are scarce, it can be assumed that there are similarities to the feeding of other asteroid taxa (Luidia spp., Patiria spp., Evasterias spp., Pisaster spp., Pycnopodia spp.) [10]. These asteroid larvae facilitate food ingestion via the beating of epidermal cilia that generate a feeding current for the concentration and ingestion of particles [10]. Particles accumulate in the mouth and are subsequently swallowed via the action of muscles surrounding the oesophagus. The sphincter between the oesophagus and stomach then opens, allowing the particles to enter the stomach where they can be sorted, digested or rejected by dorsal flexion $[10,11]$. Rejection of particles that have not reached the stomach is accomplished by a reverse beating of the oesophagus and mouth cilia, and the reverse sequence of muscle contractions. This might be a mechanism for food selection [11].

Studies of larval feeding in CoTS conducted to date have focused on size selectivity and the influence of food concentration on feeding behaviour $[7,12,13]$. In particular, these investigations have demonstrated the ability of CoTS larvae to discriminate particle ingestion based on size (feeding in the range of 5-20 $\mu \mathrm{m}$ in diameter) and a modulatory effect of algal species on feeding and development. It has also been demonstrated that CoTS larvae can feed on other organic matter, such as mucus derived from corals [14]. As suggested by Ayukai [12], ingestion is likely controlled by other factors than algae size and concentration, with food quality potentially influencing CoTS feeding behaviour. While each of the aforementioned studies contributed knowledge to our understanding of the larval phase of this species, the corresponding experiments were short in duration (approximately $30 \mathrm{~min}$ ) $[12,13]$ or conducted using high food concentrations of little relevance to natural conditions [7]. Thus, there is currently limited knowledge on the feeding ecology (e.g., preferred food items, consumption) of the larvae of this important coral predator, in particular in terms of potential preference for some algal species and corresponding consumption rates.

In the present study, larvae were fed with five different algae species that are commonly used in CoTS larval experiments or naturally occurring on the GBR (in isolation or in 1:1 choice experiments) and tested over $18 \mathrm{~h}$ of consumption. Initial and final algae concentrations were measured by flow cytometry. This technique uses the fluorescence properties of each algal species for discrimination $[15,16]$. It simultaneously computes cell concentrations and, by comparing concentrations before and after consumption by CoTS, allows the calculation of filtration and ingestion rates. Flow cytometry has been used to study feeding behaviour of several zooplankton species, including copepods [17], oyster larvae [18], zebra mussel larvae [19] and decapod larvae [20], but never for studying CoTS feeding behaviour (nor, to our knowledge, that of any other echinoderm). Therefore, flow cytometry represents an alternative to the more traditional methods implemented previously in CoTS feeding studies and potentially an efficient way to increase accuracy in algal counts [12]. Specifically, we used this technique to determine the filtration and ingestion rates of the different algal species under two different ecologically relevant algal cell concentrations. In addition, we investigated the ability of CoTS larvae to selectively ingest or reject individual algal species in food mixes. Finally, we related these patterns of food selection to the energetic content of the algae species tested.

\section{Material and Methods}

\subsection{Spawning and Maintenance of CoTS Larvae}

Adult CoTS were collected on Rudder Reef in the northern section of the GBR $\left(16.21^{\circ} \mathrm{S}, 145.47^{\circ} \mathrm{E}\right)$ in mid-September 2014, transported to the Australian Institute of Marine Science and maintained under natural flow-through seawater (FSW) conditions. Adult CoTS were spawned and oocytes fertilized as described previously [9]. Briefly, a small $(\approx 1 \mathrm{~cm})$ incision was made near the proximal end of one of the arms, and 3-4 gonadal lobes were removed from each specimen. After macroscopic sex determination, testes of six males and ovaries of six females were collected. Testes were placed in covered 6-well plates to prevent desiccation. Ovary lobes were rinsed with filtered seawater (FSW) and subsequently submerged in a $10^{-5} \mathrm{M}$ 1-methyladenine/seawater solution to induce 
maturation. After 60-70 min, mature oocytes were washed through a 50- $\mu \mathrm{M}$ mesh and oocytes from all females combined. Oocytes were diluted in seawater to achieve a stock solution of $\sim 400 \mathrm{eggs} \cdot \mathrm{mL}^{-1}$. Two millilitres of dry sperm from each male were combined and added to $2500 \mathrm{~mL}$ of the egg solution, resulting in a concentration of $10^{6}-10^{7} \mathrm{sperm} \cdot \mathrm{mL}^{-1}$. This yielded a fertilization success of $>99 \%$. After $20 \mathrm{~min}$, eggs were washed repeatedly using a 50-mm mesh to remove excess sperm. Fertilized eggs were then divided evenly across three holding tanks $\left(70 \mathrm{~L}\right.$ each) and kept at $27^{\circ} \mathrm{C}$ in FSW $(0.2 \mu \mathrm{m})$ under a $12 \mathrm{~h}: 12 \mathrm{~h}$ light dark cycle. CoTS larvae were maintained at a density of 0.6-1.5 larvae $\cdot \mathrm{mL}^{-1}$ and fed with Dunaliella sp. (3000 cells $\left.\cdot \mathrm{mL}^{-1}\right)$ once per day starting two days post-hatching. These algal species and concentration were chosen because they are known to promote optimal development in CoTS larvae (e.g. [7]). Because the feeding behaviour of CoTS larvae changes over the course of larval development [7], all experiments were conducted using larvae between 3 and 7 days old. Microscopic examination showed that all larvae were in the bipinnaria/early brachiolaria stage.

\subsection{Phytoplankton Cultures and Analysis}

CoTS larvae were fed cultured phytoplankton over the course of the feeding experiments. Five pure algae species were sourced from the Australian Algal Culture Collection (Hobart, Australia), consisting of two diatom species: Phaeodactylum tricornutum (Species No. CS-29) and Chaetoceros sp. (CS-256), two haptophytes: Pavlova lutheri (CS-182) and Tisochrysis lutea (CS-177) and the green algae Dunaliella sp. (CS-353). All algae were grown at $26^{\circ} \mathrm{C}$ under a $12 \mathrm{~h}: 12 \mathrm{~h}$ light dark cycle, in F/2 medium. Experimental algal species were selected because they have been frequently used in CoTS larval culture (Dunaliella sp., T. lutea, P. tricornutum, P. lutheri) $[7,9,13]$ or are naturally occurring on the GBR (Chaetoceros sp.) [21] and can dominate microalgal community assemblage following flood events [22]. The length and width of the microalgae were determined for 30 cells of each species under a $400 \times$ magnification.

To quantify algal nutritional content, algae were analysed for total lipid content following standardized procedures described previously [23]. Briefly, lipids were extracted with dichloromethane: methanol (2:1). Protein content was determined via the application of a nitrogen-to-protein conversion factor of 5.0, taking into account the significant sources of chlorophyll, nucleic acids, free amino acids and inorganic nitrogen [24], while the energetic content of each algal species was determined on a pg/cell basis from the enthalpies of combustion values published by Bureau et al. [25]: lipid $\left(39.5 \mathrm{~kJ} \cdot \mathrm{g}^{-1}\right)$ and protein $\left(23.9 \mathrm{~kJ} \cdot \mathrm{g}^{-1}\right)$.

Organic carbon (OC), nitrogen $(\mathrm{N})$ and chlorophyll content of each algal species were measured in duplicate using standard water quality methods (e.g., [26]). In brief, $100 \mathrm{~mL}$ (for chlorophyll) or $50 \mathrm{~mL}$ (for OC, N) of stock solution were filtered on pre-combusted 25-mm filters (Whatman GF/F) and stored frozen $\left(-20^{\circ} \mathrm{C}\right)$ until analysis. Nitrogen was analysed on an ANTEK 9000 NS analyser and OC on a Shimadzu TOC-V carbon analyser, equipped with a solid sample module (SSM-5000A) after removing inorganic carbon using $2 \mathrm{M}$ hydrochloric acid. Chlorophyll-a concentrations were measured fluorometrically (Turner Designs $10 \mathrm{AU}$ fluorometer) after grinding filters in cold $\left(4^{\circ} \mathrm{C}\right)$ acetone $(90 \%)$.

\subsection{Larval Feeding Experiments}

Each experiment corresponded to either a single algal species being tested or a mixture of two species, at either the high- or low-level treatment. Prior to incubations and for each experiment, larvae were starved for approximately $20 \mathrm{~h}$, concentrated and placed in six glass jars containing $200 \mathrm{~mL}$ of FSW. Larvae were stocked at an approximate concentration of 1 larvae. $\mathrm{mL}^{-1}$ and counted both at the beginning and the end of each experiment. Initial counts in each experiment showed that the actual numbers varied slightly (mean \pm standard deviation: $1.00 \pm 0.17$ larvae $\cdot \mathrm{mL}^{-1}$; range: $0.57-1.50$ larvae $\cdot \mathrm{mL}^{-1}$ ). We accounted for this variation by adding the actual initial larval density as a factor in the statistical model (see below). To document possible intrinsic changes in algal concentrations without larvae, six jars were used as no larvae controls and filled with $200 \mathrm{~mL}$ of FSW. 
Jars were then placed on a shaker plate and larvae starved a further five hours. Thus, larvae had sufficient time to acclimate to their new environmental conditions. Prior to each experiment, algae stock concentrations were obtained using an Accuri C6 flow cytometer. Feeding concentrations were then calculated and the respective number of algae added to each jar (experimental and control). Each jar was adjusted to a final concentration of either 1000 cells $\cdot \mathrm{mL}^{-1}$ for the low-level treatment or 2500 cells. $\mathrm{mL}^{-1}$ for the high-level treatment. These concentrations were in the range reported by Devlin et al. [22] in flood plumes on the Great Barrier Reef lagoon. In total, we therefore used 24 jars for each algal species (or mixture of species), including 12 jars for the low-level treatment (6 with larvae and 6 without larvae) and 12 jars for the high-level treatment (6 with larvae and 6 without larvae). Larval age (between 3 and 7 days old) was randomly distributed across all experiments and also accounted for in the statistical models as a fixed effect (see below).

In addition to the aforementioned experimental and control jars, three experimental (with larvae) and three control jars (without larvae) were run with Dunaliella sp. at a density of 2500 cells $\cdot \mathrm{mL}^{-1}$ during each incubation These served as an inter-experiment reference to control for possible variation in CoTS algal consumption between experiments. In other words, we obtained a feeding rate for Dunaliella sp. at a standard concentration for each experiment.

Following the addition of algae, each jar was gently agitated with a customized plunger and a $2-\mathrm{mL}$ subsample of water taken through a $100-\mu \mathrm{m}$ mesh (to avoid removing larvae). The jars were placed back on the shaker plate and left for $18 \mathrm{~h}$. All subsamples were immediately analysed with the flow cytometer and the initial algal concentration calculated. This step ensured that the actual initial algal concentrations (as measured by flow cytometry) that slightly varied around the expected value both in the single and mixed-species experiments could be taken into account in the statistical model. This step also ensured that, in each case, low- and high-level treatments spanned distinct ranges of initial algal concentrations (Table A1). After $18 \mathrm{~h}$, each jar was agitated again, and a final sample was taken and cell numbers analysed. Larvae were then counted in a $25-\mathrm{mL}$ subsample from each replicate to determine larval densities for each replicate.

We used the initial experiments to investigate the feeding rates on individual algal species. Subsequently, we conducted choice experiments with mixtures of two algal species. The four mixtures each consisted of $50 \%$ of Dunaliella sp. and $50 \%$ of either of the remaining species. Dunaliella sp. was chosen as a reference because it was commonly used in past CoTS feeding experiments $[7,9,27]$. We also limited experiments to two species at a time to ensure their accurate distinction by the flow cytometer. Two cell concentrations were used for single food and choice experiments: $1000 \mathrm{cells} \cdot \mathrm{mL}^{-1}$ for the low treatment and 2500 cells. $\mathrm{mL}^{-1}$ for the high treatment.

We calculated two important ecological parameters for plankton feeders, namely the filtration rate (i.e., the volume of water cleared by a larvae in a given amount of time) and the ingestion rate (i.e., the number of algae cells ingested per larvae per unit of time). First, we calculated the filtration rate (Fr) for each algal species according to Coughlan [28]. For each treatment, a growth constant $k$ was calculated from $C^{\prime}{ }_{0}$ and $C^{\prime}{ }_{t}$, i.e., the initial and final algae concentrations in the control jars, respectively.

$$
C_{t}^{\prime}=C_{0}^{\prime} e^{k t} \Longleftrightarrow k=\frac{1}{t} \ln \left(\frac{C_{0}^{\prime}}{C_{t}^{\prime}}\right)
$$

where $t$ is the duration of the experiment $(18 \mathrm{~h})$. A grazing coefficient $g$ was calculated in the same way from $C_{0}$ and $C_{t}$, i.e., initial and final algae concentrations in each replicate, respectively

$$
g=\frac{1}{t} \ln \left(\frac{C_{0}}{C_{t}}\right)+k
$$

The filtration (or clearance) rate $\left(\mu \mathrm{L}\right.$ larva $\left.{ }^{-1} \mathrm{~h}^{-1}\right)$ was then calculated as:

$$
F r=\frac{V}{N_{\text {larv }}} g
$$


where $N_{\text {larv }}$ is the number of larvae in the jar and $V$ the volume of water in the jar $(200 \mathrm{~mL})$.

Mean ingestion rate (cells larva ${ }^{-1} \cdot \mathrm{h}^{-1}$ ) was calculated from:

$$
I_{r}=F_{r} C_{\text {mean }}
$$

where $C_{\text {mean }}$, the mean concentration (cells $\mu \mathrm{L}^{-1}$ ), is calculated as:

$$
C_{\text {mean }}=\frac{C_{0}\left(e^{(k-g) t}-1\right)}{(k-g) t}
$$

Selective feeding by CoTS larvae in the choice experiments was then evaluated as described by Baldwin [18] and Fileman et al. [20] and through an electivity index proposed by Vanderploeg and Scavia [29]:

$$
E_{i}=\frac{F r_{i}}{\sum_{j} F r_{j}}
$$

where $F r_{i}$ is the filtration rate for algae $i$ in the mixture and the sum of filtrations rates of all species present in the mixture. For each species $i, E_{i}$ ranges between 0 and 1 , with 0.5 meaning no selectivity, $0-0.5$ representing avoidance and $0.5-1$ representing selection. The utilization of this index is particularly relevant here, because it is unaffected by the initial proportions of each algal species in the mixture [18].

\subsection{Modelling}

We predicted filtration and ingestion rates of CoTS larvae as a function of algal species and initial concentration using a Poisson error-distributed generalized linear mixed-effect model (GLMM) [30]. Initial larval concentration and age and initial algal concentrations were included in the models as fixed effects. This allowed us to (i) account for the fact that larvae of different ages (3-7 days old) might have slightly different dietary requirement and (ii) test for the effect of initial algal concentration on ingestion and filtration rates as suggested by Marin et al. [31]. All combinations of fixed effects including their interactions were considered in three model sets for each response variable (i.e., filtration and ingestion rates): (i) in single-species experiments, (ii) for Dunaliella sp. in mixed-species experiment and (iii) for the second species in the mixed-species experiments. We included the date of the experiment as a random effect to account for the non-independence of replicates tested on the same day and from the same batch of larvae.

We assessed GLMM performance using the marginal $R^{2}\left(R_{m}\right.$, variance explained by the fixed effects) and the conditional $R^{2}$ ( $R_{c}$, variance explained by both the fixed and random effects) to provide an index of the model's goodness-of-fit [32]. We also used Akaike's information criterion corrected for small sample sizes $\left(\mathrm{AIC}_{c}\right)$ that provides an index of Kullback-Leibler information loss and corresponding weights $\left(w \mathrm{AIC}_{c}\right)$ to assign the relative strengths of evidence to the different competing models [33]. This information-theoretic approach offers a more robust method than standard regression techniques for testing alternative hypotheses, because it uses a multi-model inference framework without discarding any models or predictors based on arbitrary thresholds such as $p$-values [34]. We fitted the GLMM using the function lmer (library lme4) in R 3.0.1 [35].

We then used the GLMM to compare the effect of algal species and initial concentration (high vs. low treatment) on the filtration and ingestion rates both in single- and mixed-species experiments. To do this, we predicted the partial effects of the different algae species and their initial concentrations on the filtration and ingestion rates of CoTS larvae. We used a model-averaging approach whereby predictions from each model in the model set were weighted by their relative strength of evidence $\left(w \mathrm{AIC}_{c}\right)$, then averaged. This procedure allowed the estimation of mean filtration and ingestion rates in each treatment while correcting for the known variation in initial algae concentration and the possible measurement errors due to non-independence in the original dataset. We then compared the predicted filtration and ingestion rates of each algal species in single vs. mixed species and high vs. low treatments using $t$-test pairwise comparisons. 


\section{Results}

\subsection{Single Species Experiment}

In the single-species experiments, the model predicting filtration rate from larval age, initial algal concentration and their interaction with algal species received the strongest support based on $\mathrm{AIC}_{c}$ and explained over $80 \%$ of the variation in filtration rates (with $66 \%$ attributed to fixed effects) (Table 1). The same model without the interaction between algal species and initial concentration received the strongest $\mathrm{AIC}_{c}$ support in explaining ingestion rates, accounting for up to $90 \%$ of their variation (with $74 \%$ attributed to fixed effects).

Table 1. Generalized linear mixed-effects model (GLMM) results for filtration and ingestion rates of larvae fed with a single algal species. Filtration and ingestion rates are predicted as a function of algal species, larvae concentration (LC), larvae age (LA), initial algae concentration (IC) and their interaction (as indicated by the asterisk). All models include the experimental date as the random effect. Shown are the number of model parameters $(k)$, maximum log-likelihood $(L L)$, the information-theoretic Akaike's information criterion corrected for small samples $\left(\mathrm{AIC}_{c}\right), \mathrm{AIC}_{c}$ weight $\left(w \mathrm{AIC}_{c}\right)$ marginal and conditional R-squared $\left(\mathrm{R}_{m}\right.$ and $\mathrm{R}_{\mathcal{c}}$ ) as measures of the model's goodness-of-fit. Models are ordered by decreasing $w \mathrm{AIC}_{c}$. Only models with $w \mathrm{AIC}_{c}>0.001$ are shown, in addition to the null model.

\begin{tabular}{ccccccc}
\hline Model & $\boldsymbol{k}$ & $\boldsymbol{L L}$ & $\mathbf{A I C}_{\boldsymbol{c}}$ & $\boldsymbol{w A I C}_{\boldsymbol{c}}$ & $\mathbf{R}_{\boldsymbol{m}}$ & $\mathbf{R}_{\boldsymbol{c}}$ \\
\hline Filtration rate & & & & & & \\
Species * IC + Species * LA + (1 I date) & 17 & -324.8 & 744.7 & 0.920 & 65.70 & 81.80 \\
Species * IC + Species *A + LA + (1 I date) & 18 & -322.4 & 749.5 & 0.080 & 64.50 & 82.10 \\
1 + (1 I date) & 3 & -426.1 & 858.4 & 0.000 & 0.00 & 39.80 \\
\hline Ingestion rate & & & & & & \\
Species * LA + IC + (1 I date) & 13 & -339 & 740.3 & 0.996 & 73.70 & 90.90 \\
Species + IC + LA + (1 I date) & 9 & -357.4 & 751.2 & 0.004 & 73.70 & 91.40 \\
1 + (1 I date) & 3 & -447.3 & 900.9 & 0.000 & 0.00 & 41.20 \\
\hline
\end{tabular}

Filtration rates of individual algal species were either not significantly affected by initial food concentration (Figure 1a; P. tricornutum, P. lutheri and Dunaliella sp., T. lutea; $t$-test; $p>0.05$ ) or decreased with increasing algae concentration (Chaetoceros sp.; $p<0.001$ ). When initial algae concentrations increased from 1000-2500 algae $\mathrm{mL}^{-1}$, the filtration rate for Dunaliella sp. remained around $60 \mu \mathrm{L}$ larvae ${ }^{-1} \cdot \mathrm{h}^{-1}$ for both concentrations (Figure 1a), while the ingestion rates for the same species increased from 36.3 cells larva ${ }^{-1} \cdot \mathrm{h}^{-1}$ on average (95\% confidence interval: $31.8-40.8$ ) to 87.0 (84.2-89.8) cells larva ${ }^{-1} \cdot \mathrm{h}^{-1}$ (Figure $1 \mathrm{~b}$ ). Similarly, ingestion rates significantly increased at higher algal concentrations for all algal species tested (Figure $1 ; p<0.001$ ). The lowest mean ingestion rate of 10.3 cells larvae ${ }^{-1} \cdot \mathrm{h}^{-1}(5.9-14.8)$ was observed for P. lutheri in the 1000 cells $\cdot \mathrm{mL}^{-1}$ concentration, while the highest one, 104.3 cells larva ${ }^{-1} \mathrm{~h}^{-1}$ on average (96.4-112.1), was found for T. lutea under the 2500 cells $\cdot \mathrm{mL}^{-1}$ concentration.

CoTS larvae filtered and ingested T. lutea, Dunaliella sp. and Chaetoceros sp. at higher rates (filtration $>63.1 \mu \mathrm{L} \cdot \mathrm{larva}^{-1} \cdot \mathrm{h}^{-1}$ and ingestion $>77.2$ cells larva ${ }^{-1} \cdot \mathrm{h}^{-1}$ for the high treatment), compared to rates of filtration and ingestion for P. tricornutum and P. lutheri (28.5 and $24.6 \mu \mathrm{L} \cdot$ larva $^{-1} \cdot \mathrm{h}^{-1}$ for filtration and 63.0 and 46.4 cells larva ${ }^{-1} \cdot \mathrm{h}^{-1}$ for ingestion, respectively) (Figure 1). 
a. Filtration

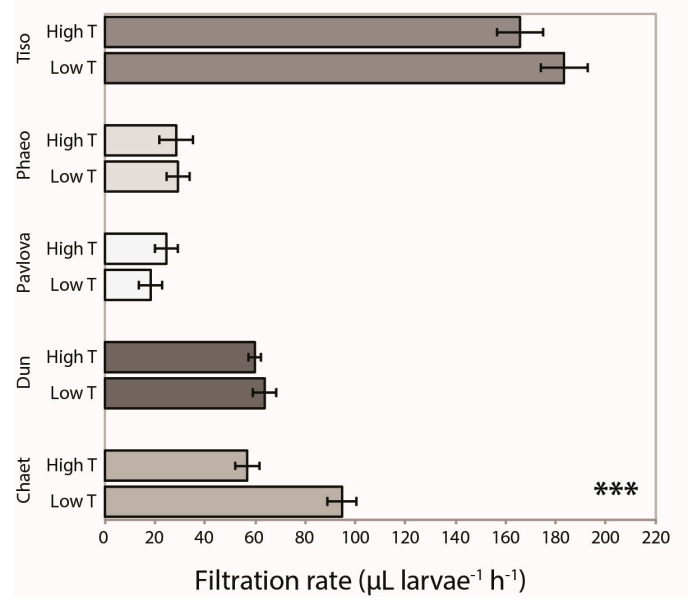

b. Ingestion

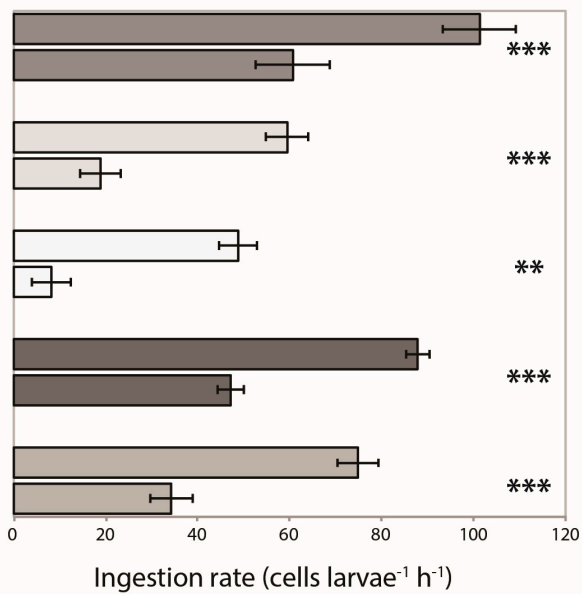

Figure 1. Filtration and ingestion rates for larvae fed with one algal species. Predicted filtration (a) and ingestion (b) rates of larvae fed with five different species. Predictions are made using GLMM models. High treatment represents an initial concentration of 2500 cells $\cdot \mathrm{mL}^{-1}$ and low treatment an initial concentration of 1000 cells $\cdot \mathrm{mL}^{-1}$. The error bars represent the $95 \%$ confidence intervals. Asterisks represent significantly different rates between low- and high-concentration treatments (Student's $t$-test; $\left.{ }^{*}: p<0.05,{ }^{* *}: p<0.01 ;{ }^{* *}: p<0.001\right)$. Tiso: Tisochrysis lutea; Phaeo: Phaeodactylum tricornutum; Pavlova: Pavlova lutheri; Dun: Dunaliella sp.; Chaet: Chaetoceros sp.

\subsection{Mixed Species Experiments}

In the mixed-species experiments, the model including larvae age and the interaction between algal species and initial algal concentrations (both species) received the strongest $\mathrm{AIC}_{c}$ support in explaining both the filtration and ingestion rates for Dunaliella sp. (Table 2). This model explained 63 and $87 \%$ of variation in Dunaliella sp. filtration and ingestion rates, respectively (with $27 \%$ and $71 \%$ attributed to fixed effects). The same model also received the strongest support in explaining filtration and ingestion rates for the second species (with $79 \%$ and $92 \%$ of variation explained in filtration and ingestion rates, respectively) (Table 3).

In a similar manner to the trends observed in single algal experiments, all larval ingestion rates increased with initial algal concentration $(p<0.05$; Table 4) (Figure 2). Conversely, the filtration rates remained constant for P. tricornutum and P. lutheri, as well as for Dunaliella sp. when mixed with either P. tricornutum or P. lutheri $(p>0.05)$, but significantly decreased for T. lutea and Chaetoceros sp. $(p<0.001)$ (Table 4).

Table 2. Generalized linear mixed-effects model (GLMM) results for filtration and ingestion rates of Dunaliella sp. for larvae fed with 1:1 mixture. Filtration and ingestion rates of Dunaliella sp. are predicted as a function of algal species, larvae concentration (LC), larvae age (LA), initial algae concentration of Dunaliella sp. (IC dun), initial algal concentration for the second species (IC) and their interaction (as indicated by the asterisk). All models include the experimental date as the random effect. Shown are the number of model parameters (k), maximum log-likelihood (LL), the information-theoretic Akaike's information criterion corrected for small samples $\left(\mathrm{AIC}_{c}\right), \mathrm{AIC}_{c}$ weight $\left(w \mathrm{AIC}_{c}\right)$ marginal and conditional $\mathrm{R}$-squared $\left(\mathrm{R}_{m}\right.$ and $\mathrm{R}_{c}$ ) as measures of the model's goodness-of-fit. Models are ordered by decreasing $w \mathrm{AIC}_{c}$. Only models with $w \mathrm{AIC}_{c}>0.001$ are shown, in addition to the null model.

\begin{tabular}{cllllll}
\hline Model & $\mathbf{k}$ & $\mathbf{L L}$ & $\mathbf{A I C}_{\boldsymbol{c}}$ & $\boldsymbol{w}_{\mathbf{A I C}}$ & $\mathbf{R}_{\boldsymbol{m}}$ & $\mathbf{R}_{\boldsymbol{c}}$ \\
\hline Filtration rate & & & & & & \\
Species * IC * IC dun + LA + (1 I date) & 22 & -317.1 & 779.9 & 0.980 & 27.0 & 63.5 \\
Species * IC * IC dun + LA + LA + (1 I date) & 23 & -315 & 788.7 & 0.012 & 29.0 & 68.6 \\
Species * IC + Species * IC dun + Species * LA + (1 I date) & 21 & -328.3 & 790.2 & 0.006 & 27.5 & 67.5 \\
\hline
\end{tabular}


Table 2. Cont

\begin{tabular}{ccccccc}
\hline Model & $\mathbf{k}$ & $\mathbf{L L}$ & $\mathbf{A I C}_{\boldsymbol{c}}$ & $\boldsymbol{w A I C}_{\boldsymbol{c}}$ & $\mathbf{R}_{m}$ & $\mathbf{R}_{\boldsymbol{c}}$ \\
\hline Species * IC + Species * IC dun + LA + (1 I date) & 17 & -349.7 & 792.3 & 0.002 & 26.8 & 64.3 \\
1 + (1 I date) & 3 & -422.4 & 851.1 & 0.000 & 0.0 & 38.0 \\
Ingestion rate & & & & & & \\
Species * IC * IC dun + LA + (1 I date) & 22 & -243.8 & 633.3 & 0.980 & 71.4 & 87.2 \\
Species* IC + Species * IC dun + LA + (1 I date) & 17 & -274.6 & 642.3 & 0.011 & 69.2 & 86.7 \\
Species * IC * IC dun + LA + LA + (1 I date) & 23 & -242.4 & 643.6 & 0.006 & 71.3 & 88.0 \\
1 + (1 I date) & 3 & -399.4 & 805 & 0.000 & 0.0 & 27.8 \\
\hline
\end{tabular}

Table 3. Generalized linear mixed-effects model (GLMM) results for filtration rates and ingestion rates of the second species for larvae fed with 1:1 mixture. Filtration and ingestion rates of the second species offered along Dunaliella sp. in a 1:1 mixture are predicted as a function of algal species, larvae concentration (LC), larvae age (LA), initial algae concentration of Dunaliella sp. (IC dun), initial algal concentration for the second species (IC) and their interaction (as indicated by the asterisk). All models include the experimental date as the random effect. Shown are the number of model parameters (k), maximum log-likelihood (LL), the information-theoretic Akaike's information criterion corrected for small samples $\left(\mathrm{AIC}_{c}\right), \mathrm{AIC}_{c}$ weight $(w \mathrm{AIC} c)$ and the marginal and conditional R-squared $\left(\mathrm{R}_{m}\right.$ and $\left.\mathrm{R}_{c}\right)$ as measures of the model's goodness-of-fit. Models are ordered by decreasing $w \mathrm{AIC}_{c}$. Only models with $w \mathrm{AIC}_{c}>0.001$ are shown, in addition to the null model.

\begin{tabular}{|c|c|c|c|c|c|c|}
\hline Model & $\mathbf{k}$ & LL & $\mathrm{AIC}_{c}$ & $w \mathrm{AIC}_{c}$ & $\mathbf{R}_{m}$ & $\mathbf{R}_{c}$ \\
\hline \multicolumn{7}{|l|}{ Filtration rate } \\
\hline Species ${ }^{*}$ IC $*$ IC dun + LA + (1 I date $)$ & 22 & -317.3 & 780.4 & 0.985 & 75.0 & 79.4 \\
\hline Species * IC * IC dun + LA + LA + (1 I date $)$ & 23 & -316 & 790.7 & 0.006 & 74.3 & 79.6 \\
\hline Species * IC + Species * IC dun $+(1 \mid$ date $)$ & 16 & -353.3 & 790.9 & 0.005 & 75.5 & 80.1 \\
\hline Species * IC + Species * IC dun + LA + (1 I date $)$ & 17 & -349.7 & 792.4 & 0.002 & 75.1 & 80.0 \\
\hline Species $*$ IC + Species $*$ IC dun + Species ${ }^{*}$ LA $+(1$ I date $)$ & 21 & -329.6 & 793.0 & 0.002 & 74.7 & 79.6 \\
\hline $1+(1 \mid$ date $)$ & 3 & -461.6 & 929.4 & 0.000 & 0.0 & 39.9 \\
\hline \multicolumn{7}{|l|}{ Ingestion rate } \\
\hline Species * IC * IC dun + LA + (1 I date $)$ & 22 & -243.2 & 632.2 & 0.980 & 83.4 & 91.9 \\
\hline Species ${ }^{*}$ IC + Species $*$ IC dun + LA + (1 I date $)$ & 17 & -274 & 640.9 & 0.012 & 81.2 & 91.2 \\
\hline Species * IC * IC dun + LA + LA + (1I date $)$ & 23 & -242.2 & 643.1 & 0.004 & 83.1 & 92.1 \\
\hline Species * IC + Species * IC dun $+(1$ I date $)$ & 16 & -279.6 & 643.5 & 0.003 & 78.9 & 91.4 \\
\hline $1+(1 \mid$ date $)$ & 3 & -410.1 & 826.5 & 0.000 & 0.0 & 45.0 \\
\hline
\end{tabular}

Table 4. Morphometry, chemical composition and energetic value of the five algal species on a per cell basis (mean and 95\% confidence interval, in brackets). Values pertaining to lipid, carbon, nitrogen and chlorophyll concentration (pg/cell) were obtained via direct analytical measurement, whilst protein concentration and energetic content were calculated according to published conversion factors. For each species, a sample size of $N=30$ was used to determine the length and width, and $N=2$ for the other parameters.

\begin{tabular}{|c|c|c|c|c|c|}
\hline Variable (unit) & Dunaliella sp. & T. lutea & Chaetoceros sp. & P. lutheri & P. tricornutum \\
\hline \multirow[t]{2}{*}{ Length $(\mu \mathrm{m})$} & 7.92 & 5.01 & 9.18 & 5.91 & 18.92 \\
\hline & $(7.37-8.47)$ & $(4.77-5.25)$ & $(8.65-9.72)$ & $(5.51-6.3)$ & $(17.94-19.9)$ \\
\hline \multirow[t]{2}{*}{ Width $(\mu \mathrm{m})$} & 5.43 & 5.7 & 6.5 & 5.17 & 3.48 \\
\hline & $(5.15-5.71)$ & $(5.46-5.94)$ & $(6.1-6.9)$ & $(4.94-5.4)$ & $(3.31-3.64)$ \\
\hline \multirow{2}{*}{ Carbon (pg/cell) } & 33.29 & 15.39 & 49.87 & 22.97 & 24.2 \\
\hline & $(33.01-33.58)$ & (15.09-15.68) & $(48.56-51.18)$ & $(22.14-23.79)$ & (23.71-24.69) \\
\hline \multirow[t]{2}{*}{ Nitrogen (pg/cell) } & 6.58 & 2.53 & 7.9 & 3.57 & 3.85 \\
\hline & $(6.54-6.61)$ & $(2.44-2.62)$ & $(7.44-8.36)$ & $(3.52-3.62)$ & $(3.73-3.97)$ \\
\hline \multirow[t]{2}{*}{$\mathrm{C} / \mathrm{N}$} & 5.06 & 6.07 & 6.31 & 6.42 & 6.27 \\
\hline & $(4.99-5.13)$ & $(5.97-6.17)$ & $(6.11-6.51)$ & $(6.28-6.57)$ & $(6.2-6.34)$ \\
\hline \multirow[t]{2}{*}{ Chlorophyll (pg/cell) } & 1.05 & 0.35 & 0.75 & 0.58 & 0.31 \\
\hline & $(0.99-1.12)$ & $(0.32-0.38)$ & $(0.7-0.8)$ & $(0.55-0.6)$ & $(0.3-0.33)$ \\
\hline
\end{tabular}


Table 4. Cont.

\begin{tabular}{cccccc}
\hline Variable (unit) & Dunaliella sp. & T. lutea & Chaetoceros sp. & P. lutheri & P. tricornutum \\
\hline Lipid $(\mathrm{pg} /$ cell) & 15.58 & 6.79 & 17.33 & 10.54 & 9.93 \\
& $(15.49-15.66)$ & $(5.48-8.09)$ & $(16.53-18.13)$ & $(8.96-12.12)$ & $(9.5-10.36)$ \\
Protein $(\mathrm{pg} /$ cell) & 32.9 & 12.65 & 39.5 & 17.85 & 19.25 \\
& $(32.7-33.05)$ & $(12.2-13.1)$ & $(37.2-41.8)$ & $(17.6-18.1)$ & $(18.65-19.85)$ \\
Energy $\left(10^{-9} \mathrm{~kJ} /\right.$ cell) & 1.39 & 0.57 & 1.62 & 0.84 & 0.85 \\
& $(1.38-1.40)$ & $(0.50-0.63)$ & $(1.53-1.70)$ & $(0.77-0.91)$ & $(0.81-0.88)$ \\
\hline
\end{tabular}
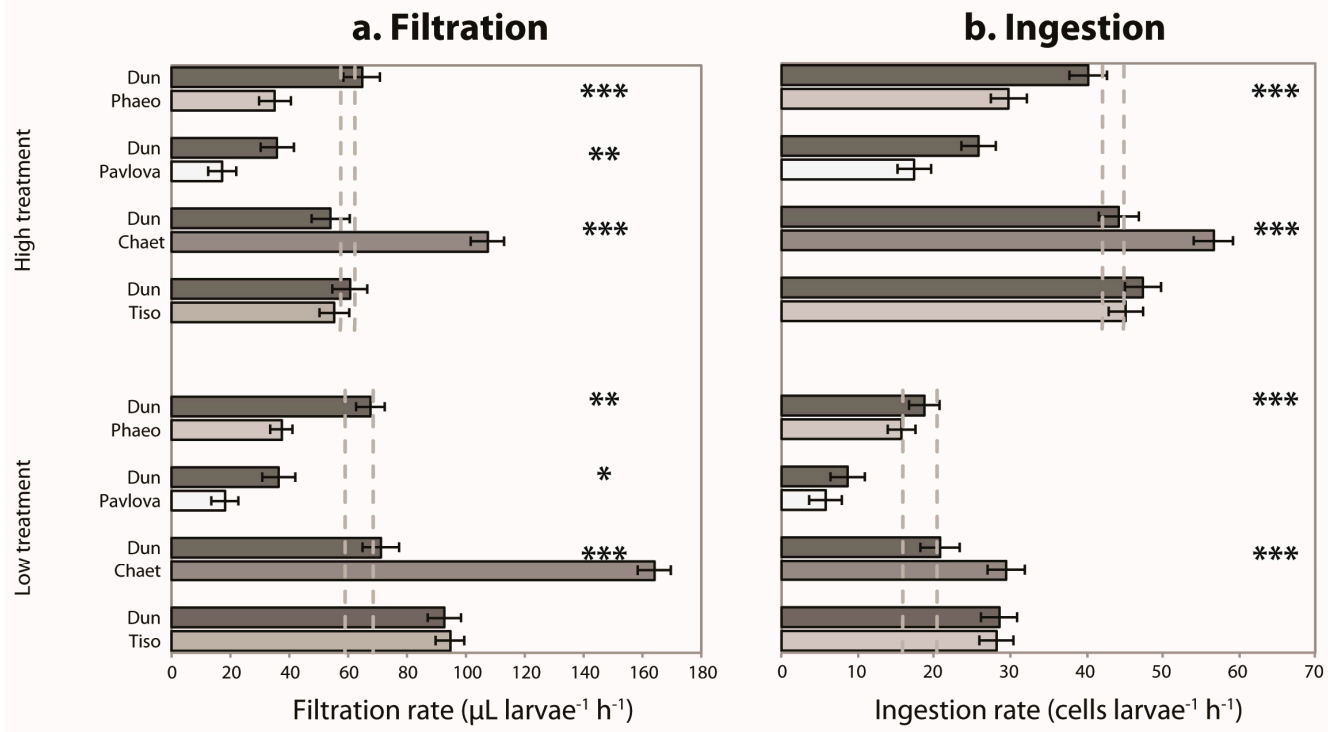

Figure 2. Filtration and ingestion rates for larvae fed with a 1:1 mixture of two algae species. Predicted filtration (a) and ingestion (b) rates for each of the two algae for the four food mixtures. Predictions are made using GLMM models. High treatment represents an initial concentration of $2500 \mathrm{cells} \cdot \mathrm{mL}^{-1}$ (1250 cells $\mathrm{mL}^{-1}$ of each species) and low treatment an initial concentration of 1000 cells $\cdot \mathrm{mL}^{-1}$ ( 500 of each species). The error bars represent the confidence intervals. The grey dotted lines represent the predicted $95 \%$ confidence interval of filtration and ingestion rates for larvae fed with Dunaliella sp. alone (filtration rate for 2500 and 1000 cells $\mathrm{mL}^{-1}$, half of the ingestion rate for 2500 and 1000 cells $\cdot \mathrm{mL}^{-1}$ of Dunaliella sp.). Asterisks represent significantly different rates between Dunaliella sp. and the second species (Student's $t$-test; * $p<0.05,{ }^{* *}: p<0.01$; ${ }^{* * *}: p<0.001$ ). Tiso: Tisochrysis lutea; Phaeo: Phaeodactylum tricornutum; Pavlova: Pavlova lutheri; Dun: Dunaliella sp.; Chaet: Chaetoceros sp.

Differences in filtration and ingestion rates between high and low treatments were significant for all species $(p<0.05)$, except for the filtration rate of Dunaliella sp. when mixed with P. lutheri $(p=0.50)$ or P. tricornutum ( $p=0.81)$ or that of P. lutheri when mixed with Dunaliella sp. $(p=0.90)$. When offered in a 1:1 mixture, the ingestion rate for Chaetoceros sp. was higher than for Dunaliella sp. regardless of the initial concentration (56.6 and 44.2 cells larvae ${ }^{-1} \cdot \mathrm{h}^{-1}$, respectively, in the high treatment) $(p<0.001$; Figure $2 b$ ). In contrast, ingestion rates of $P$. lutheri $\left(17.3\right.$ cells larvae ${ }^{-1} \cdot \mathrm{h}^{-1}$ ) and $P$. tricornutum (29.7 cells larvae $\left.{ }^{-1} \cdot \mathrm{h}^{-1}\right)$ in the high treatment were lower than those observed for Dunaliella sp. (25.8 and 40.2 cells larvae ${ }^{-1} \cdot \mathrm{h}^{-1}$ for each mixture, respectively), although the difference was only significant for P. tricornutum. T. lutea was ingested at a similar rate to Dunaliella sp. $(p>0.05)$ (Figure $2 b)$. These results are further substantiated by the electivity indexes (Figure 3): Dunaliella sp. was preferably consumed over both P. tricornutum and P. lutheri, but not over Chaetoceros sp. There was no significant difference in electivity between Dunaliella sp. and T. lutea. These preferences for individual algae were independent of algal concentration at the two different concentrations measured. 


\section{Electivity indices}

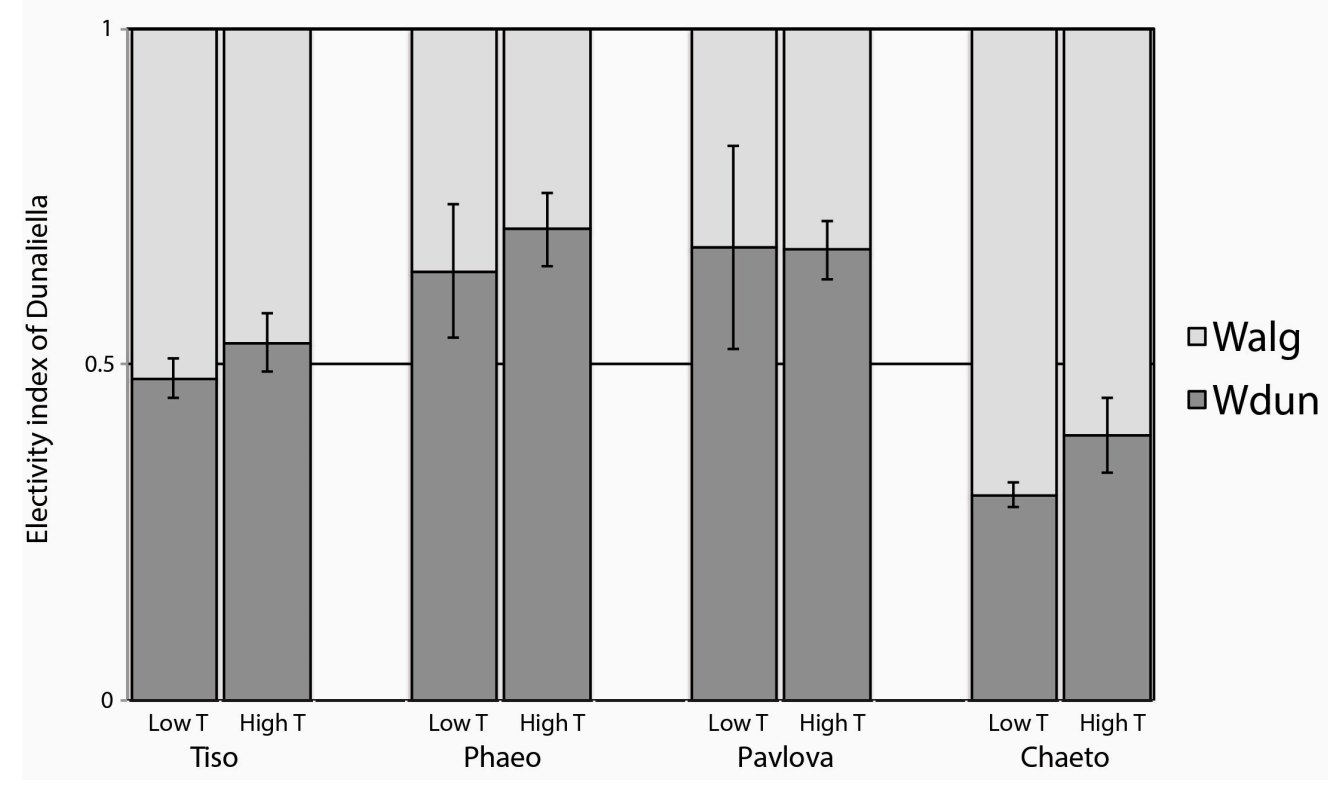

Figure 3. Electivity indices for larvae fed with a 1:1 mixture of two algal species. Mean electivity index for each of the for food mixtures. High treatment (High T) represents an initial concentration of 2500 cells $\cdot \mathrm{mL}^{-1}$ (1250 cells $\mathrm{mL}^{-1}$ of each species). Low treatment (Low $\mathrm{T}$ ) corresponds to an initial concentration of 1000 cells $\cdot \mathrm{mL}^{-1}$ (500 of each species). The lower bars (Wdun, dark grey) represent the electivity for Dunaliella sp. and the upper bars (Walg, light grey) represent the electivity for the second algae present in the mixture. Electivity "Wdun" above 0.5 (grey dotted line) indicates that the larvae selectively ingested Dunaliella sp. over the other species. The error bars are $95 \%$ confidence interval.

The importance of the predictor "species" in all models of filtration and ingestion rates for Dunaliella sp. (Table 2) and for the second species (Table 3) showed that both rates were significantly influenced by the presence of the other species. This effect was mainly caused by P. lutheri: when Dunaliella sp. was offered combined with P. lutheri, its ingestion rate (25.8 algae larvae $\left.{ }^{-1} \cdot \mathrm{h}^{-1}\right)$ was reduced compared to when Dunaliella sp. was offered in isolation (44.2 algae larvae ${ }^{-1} \cdot \mathrm{h}^{-1}$ ) (dashed line on Figure 2b, top panel). The presence of other species did not have a significant effect on Dunaliella sp. consumption, with the exception of T. lutea at the low concentration. In that case, the consumption of Dunaliella sp. appeared slightly enhanced in the presence of T. lutea: indeed, we measured an ingestion rate of 28.5 algae larvae ${ }^{-1} \cdot \mathrm{h}^{-1}$ for 500 algae $\mathrm{mL}^{-1}$ of Dunaliella sp. offered in a 1:1 mixture with T. lutea against 20.3 algae larvae ${ }^{-1} \cdot \mathrm{h}^{-1}$ for twice the same amount of Dunaliella sp. offered as a single species (Figure 2).

\subsection{Algae Quality}

The five algal species presented a variety of morphologies and crude nutritional compositions (Table 4). P. tricornutum was long and thin in shape, whereas the other species were roughly spherical. All species were of a different size, Chaetoceros sp. being the widest and, with a length of $9.2 \mu \mathrm{m}$, the second longest after P. tricornutum $(18.9 \mu \mathrm{m}$ in length). The content of each species varied with respect to the concentration (pg.cell ${ }^{-1}$ ) of total lipid, total protein, carbon, nitrogen and chlorophyll. In accordance with its larger size, Chaetoceros sp. contained the highest cell-specific content of all constituents with the exception of chlorophyll, which was found in highest abundance in Dunaliella sp. (Table 4). Conversely, T. lutea (the smallest species) contained the lowest concentrations of these constituents followed by P. lutheri and P. tricornutum. Differences in crude nutritional composition subsequently manifested in clear trends relating to the energetic content of the algal cells. Chaetoceros sp. and Dunaliella sp. contained the highest energy levels with $1.6 \times 10^{-9}$ and $1.4 \times 10^{-9} \mathrm{~kJ} \cdot \mathrm{cell}^{-1}$, 
respectively, while in comparison, T. lutea contained less than half the amount of total energy $\left(0.6 \times 10^{-9} \mathrm{~kJ} \cdot \mathrm{cell}^{-1}\right)$.

Based on algal energetic contents combined with effective ingestion rates, the greatest energy gain in the single species experiment resulted from the ingestion of Dunaliella sp. in the high concentration treatment $\left(12.210^{-8} \cdot \mathrm{kJ} \cdot \mathrm{larvae}^{-1} \cdot \mathrm{h}^{-1}\right)$. In the same experiment, the greater ingestion of T. lutea only resulted in $5.710^{-8} \mathrm{~kJ} \cdot \mathrm{larvae}^{-1} \cdot \mathrm{h}^{-1}$ due to its lower energy content. In the mixed-species experiment, the greatest energy gain was obtained from the ingestion of Dunaliella sp. and Chaetoceros sp. in combination (15.32 $10^{-8} \mathrm{~kJ} \cdot$ larvae $\left.{ }^{-1} \cdot \mathrm{h}^{-1}\right)$ followed by that of Dunaliella sp. mixed with T. lutea $\left(9.1510^{-8} \mathrm{~kJ} \cdot\right.$ larvae $\left.^{-1} \cdot \mathrm{h}^{-1}\right)$.

\section{Discussion}

Acanthaster cf. solaris (CoTS) larvae on the Great Barrier Reef are exposed to a diverse array of food choices to fuel their development through to settlement and metamorphosis [36]. The rate at which they select and consume these food items ultimately drives their rate of development and probability of survival, which is likely a major driver of CoTS population dynamics and probability of outbreak [37,38]. In the current experiments, algal consumption by CoTS larvae increased with algal concentration. As generally observed for other echinoderm larvae [10] and in CoTS subjected to short-term experiments with algal concentrations similar to those used here $[7,12,13]$, this result is directly linked to an increased opportunity for larvae-algae interactions when algae are provided in abundance. However, clear differences appeared in larval consumption based on the algal species and quantity being offered (Figure 4).

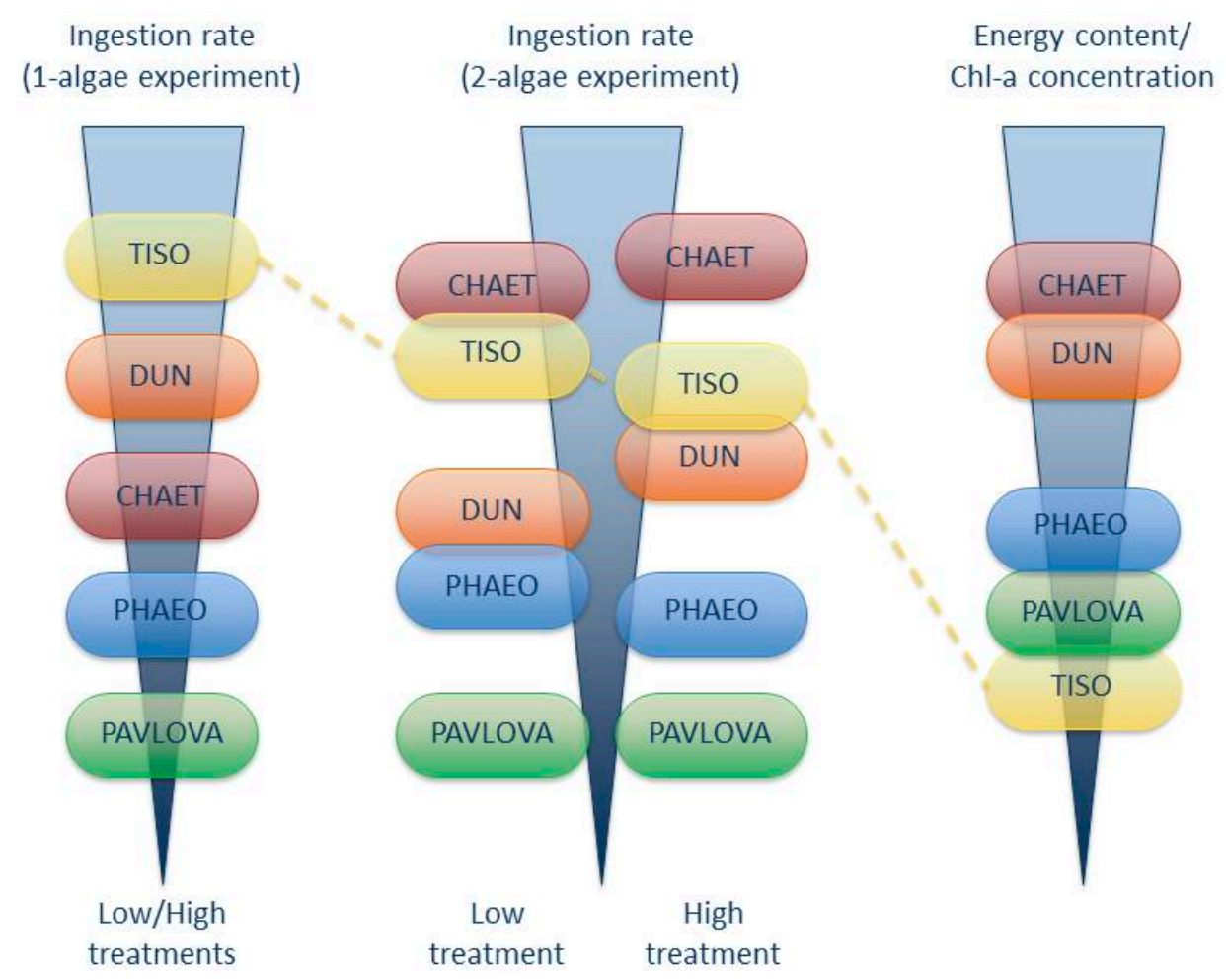

Figure 4. Conceptual synthesis of the results indicating relatively consistent ranking of the algal species based on ingestion rates (left and middle) and energy content (right), with the exception of Tisochrysis lutea (yellow). Overlapping bullets indicate non-significant differences (left and middle) or ambiguous ranking (right; e.g. Chaetoceros sp. had the highest energy content, but Dunaliella sp. had the greatest chlorophyll-a concentration; see Table 4 for details). Only Tisochrysis lutea showed an inverse ranking across gradients (as indicated by the dashed yellow line). TISO: Tisochrysis lutea; DUN: Dunaliella sp.; CHAET: Chaetoceros sp.; PHAEO: Phaeodactylum tricornutum; PAVLOVA: Pavlova lutheri. 
The ability of CoTS larvae to discriminate and select the food they ingest was evident in the present study. Aside from the particular case of T. lutea (see below), Dunaliella sp. or Chaetoceros sp. were selectively ingested over P. lutheri and P. tricornutum in both the single- and mixed-species experiments (Figure 4). In particular, in the mixed-species experiment, a clear preference appeared for Chaetoceros sp., which was selectively ingested over Dunaliella sp. In contrast, Dunaliella sp. was preferred over both P. lutheri and P. tricornutum, as indicated by the lower ingestion rates and electivity indices observed for these two species. Chaetoceros sp. was the only species naturally present on the Great Barrier Reef, which could explain why it was selectively ingested over other species. Interestingly, these results also follow the trends observed in food quality and energy content, with Chaetoceros sp. having the highest content of energy, lipid, protein, carbon and nitrogen, whereas the lowest energy content was found for P. lutheri followed by P. tricornutum. This result indicates that, when offered a mixture of two algal species, CoTS larvae selectively ingested the species with higher energetic content when cells are present in abundant concentration. Consumption can be driven by the presence of primary metabolites (e.g., proteins, amino acids, sugars), with individual food items exhibiting unique primary metabolite ratios that distinguish one food source over another [39]. However, other factors relevant to cell morphometry, anti-nutritional factors and cell wall digestibility (among others) cannot be overlooked, and the exact mechanisms behind this discriminatory ability ultimately require further investigation.

Algal species that were selectively avoided by CoTS larvae (P. lutheri, P. tricornutum) were both characterized by lower energy content (Figure 4), which can lead to lower development and survival rates. Indeed, Lucas [7] found differences in development and survival for larvae fed with different algal species, with larvae fed with $P$. lutheri rarely making it through their development cycle. In addition to energy content, the size and/or shape of a particular algal species could also influence its selective ingestion by CoTS larvae, with the second least preferred species (P. tricornutum) being the only long and thin one. Okaji et al. [13] showed an effect of phytoplankton size on feeding rates, as well as a preference for eukaryotes over cyanobacteria (probably also resulting from their difference in size). Okaji et al. [13] also demonstrated that CoTS typically consume particles of 5-20 $\mu \mathrm{m}$ in equivalent spherical diameter. The length of P. tricornutum $(19 \mu \mathrm{m})$, being close to the end of this range, is thus likely to hinder its ingestion by CoTS larvae. Furthermore, the thick cell walls of $P$. tricornutum could also reduce the rates of digestion and assimilation [7].

The case of T. lutea was somewhat particular in that no preference or avoidance was detected in the mixed-species experiment, yet T. lutea was ingested at a much higher rate when offered as a single species (Figure 4). Its low energy content meant that, despite more algal cells being ingested, the consumption of this species led to the lowest energy gain for CoTS larvae. Such an impact was demonstrated for other zooplankton species: for example, Baldwin [18] showed that oyster larvae ingestion rates were three times higher for algae with a low $\mathrm{C} / \mathrm{N}$ ratio than for algae with a high ratio. Here, T. lutea was characterized by the lowest nitrogen content and second lowest $\mathrm{C} / \mathrm{N}$ ratio, indicating that CoTS larvae would need to consume more of this species than the others to satisfy energy requirements.

The interaction between algal species affected their filtration and ingestion rates by CoTS larvae, with both rates for Dunaliella sp. being significantly influenced by the other species present in the mixture. Notably, the presence of $P$. lutheri reduced the ingestion of Dunaliella sp. by CoTS larvae, without increased uptake of the former species. A similar phenomenon was previously reported for larvae of the brittle star Ophiopholis aculeata and the sea urchin Strongylocentrotus droebachiensis [10]. In these species, the presence of the diatom Ditylum brightwellii reduced the feeding rate on smaller celled algae. Similarly, the inadvertent ingestion of $P$. lutheri by CoTS larvae may have stopped the larvae from feeding all together, but the exact mechanisms underpinning food selection (and how the ingestion of one species influences that of another) remain unclear. In fact, the filtration theory for suspension feeders is still controversial, as it does not explain the variable ingestion rates observed for different particles [40,41]. A study on sand dollar Dendraster excentricus larvae found that they 
selectively fed on specific particles and refused to capture or ingest others [42], while a more recent study showed that those larvae concentrated food particles without filtration [43]. Instead they use a different mechanism, actively capturing the particles by reversing the beat of a small portion of their cilia. In doing so, they reversed the movement of a small and targeted amount of water and were thus able to select which particle to consume. The ability of CoTS larvae to select their food could be explained by such a mechanism, but this hypothesis needs to be further investigated.

The ingestion and filtration rates found in this study were consistent with those reported by Lucas [7] based on incubation times of $24 \mathrm{~h}$, but differed from the higher rates reported by Ayukai [12] and Okaji et al. [13] in short-term studies (5-30 min). In a copepod feeding experiment, Frost [44] found that copepods had abnormally high ingestion rates during the first few hours of feeding, which could be an artefact of the imposed period of starvation prior to the beginning of the experiment. As such, the high feeding rates reported by Ayukai [12] and Okaji et al. [13] likely correspond to the elevated cell intake that manifested only over a short experimental duration.

Preference for a particular algal species is likely to be taxon-specific. Together with T. lutea, P. lutheri represented the best diet for the larvae of Saccostrea commercialis, a commercially important oyster [45]. Pecten maximus larvae (scallop) have been shown to perform favourably when subjected to P. lutheri as a food source, but poorly when Dunaliella tertiolecta was offered [46]. In contrast, in the present study, CoTS larvae exhibited a significant preference for Dunaliella sp. over P. lutheri, a trend previously observed for Crassostrea gigas larvae (oyster) [47]. Indeed, oyster larvae fed with P. lutheri exhibited significantly lower growth and survival rates than the same larvae fed with Chaetoceros calcitrans [47]. Similar to CoTS, this trend might reflect the positive effect of a more energetic food source on ingestion and subsequently growth and survival. However, although facultative food intake in the early life stage of echinoids can influence individual condition, this does not necessarily translate into differences in growth and individual size [48]. Nutritional requirements seem to vary widely between species and life stages, meaning that the presence/absence of a single essential nutrient (specific to each species and development stage) will likely have a major impact on larval performance.

Phytoplankton concentration in the natural environment is often estimated using chlorophyll- $a$ concentration as a proxy. On the Great Barrier Reef, long-term monitoring programs on the inner shelf region estimated a chlorophyll- $a$ concentration of $0.5 \mu \mathrm{g} \cdot \mathrm{L}^{-1}$ on average [4], ranging between 0.2 and $4.6 \mu \mathrm{g} \cdot \mathrm{L}^{-1}$ in flood plumes [22]. In this experiment, chlorophyll- $a$ concentrations ranged from $0.3-1.0 \mu \mathrm{g} \cdot \mathrm{L}^{-1}$ in the low treatment $\left(1000 \mathrm{cells} \cdot \mathrm{ml}^{-1}\right)$ and from $0.8-2.6 \mu \mathrm{g} \cdot \mathrm{L}^{-1}$ in the high treatment ( 2500 cells $\cdot \mathrm{mL}^{-1}$ ), which is consistent with the ranges reported on the Great Barrier Reef.

Phytoplankton composition is highly variable through different regions and flood conditions [22], yet little is known on the exact species being present, their seasonal succession and spatial distribution. Likewise, information pertaining to the energetic content and nutritional value of these species is minimal and requires in-depth investigation. This is especially apparent considering the discriminatory feeding nature of CoTS and the previous demonstration of nutritional augmentation of growth and survival in other larval echinoderm species in response to varying phytoplankton feed sources [49]. The highest phytoplankton concentrations in flood plumes of the Great Barrier Reef were dominated by

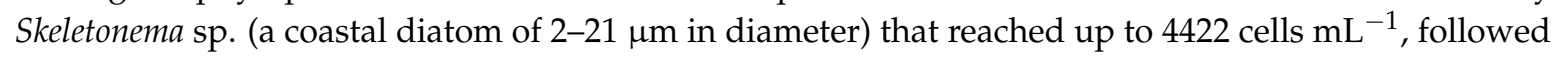
by Chaetoceros sp., which reached concentrations of 150 cells $\mathrm{mL}^{-1}$ [22]. Although the other algal species considered in this study are commonly used in aquaculture and in the size range consumed by CoTS, they are not naturally present on the Great Barrier Reef, and future studies should focus on natural assemblages, pending sufficient knowledge of their composition. In particular, future studies should consider using Skeletonema sp., although its chain-forming nature indicates it is an unlikely food for echinoderm larvae and may hamper its quantification by flow cytometry. Consistent with previous studies (e.g., [7-9,38]), we used larval densities between 0.5 and 1.5 larvae $\cdot \mathrm{mL}^{-1}$, which is much higher than reported in the only published studies on CoTS natural larval densities [50]. Although studies at such low densities are near impossible to conduct, future studies should investigate how lower larval densities affect CoTS larval feeding ecology. High-throughput genetic techniques, such as next 
generation sequencing, now allow further insight into GBR phytoplankton dynamics and composition. Ultimately, improved knowledge of phytoplankton composition and its effect on food uptake by CoTS larvae will help elucidate the CoTS outbreak dynamics and triggers.

Acknowledgments: We are grateful to Steve Moon and the Association of Marine Park Tourism Operators for their ongoing assistance to obtain study animals. Research was carried out in the National Sea Simulator (SeaSim) and we are grateful for the support of the SeaSim staff. All collections have been conducted under Great Barrier Reef Marine Park Permit No. GBRMPA Permit G38062.1. CM was funded by an Australian Research Council grant (DE140100701).

Author Contributions: S.U., D.F. and K.O. conceived of and designed the experiments. C.L. performed the experiments. C.M. and C.L. analysed the data. S.U., D.S.F. and K.O. contributed materials and analysis tools. C.M. and C.L. wrote the paper, with contributions from all other authors.

Conflicts of Interest: The authors declare no conflict of interest.

\section{Appendix A}

Table A1. Initial algal concentrations determined by flow cytometry in comparison to expected values.

\begin{tabular}{|c|c|c|c|}
\hline \multirow[b]{2}{*}{ Experiment/Treatment } & \multirow{2}{*}{$\begin{array}{l}\text { Expected Initial } \\
\text { Concentration } \\
\left(\text { cells } \cdot \mathrm{mL}^{-1}\right)\end{array}$} & \multicolumn{2}{|c|}{ Actual Measured Concentration $\left(\right.$ cells $\left.\cdot \mathrm{mL}^{-1}\right)$} \\
\hline & & $\begin{array}{l}\text { Mean } \pm \text { Standard } \\
\text { Deviation }\end{array}$ & Minimum-Maximum \\
\hline \multicolumn{4}{|l|}{ Single-species } \\
\hline Low concentration & 1000 & $848 \pm 180$ & $520-1210$ \\
\hline High concentration & 3000 & $2563 \pm 500$ & $1530-3780$ \\
\hline \multicolumn{4}{|l|}{$\begin{array}{l}\text { Mixed-species } \\
\text { total concentration) }\end{array}$} \\
\hline Low concentration & 1000 & $947 \pm 131$ & $740-1310$ \\
\hline High concentration & 3000 & $848 \pm 180$ & $1860-3630$ \\
\hline \multicolumn{4}{|l|}{$\begin{array}{c}\text { Mixed-species } \\
\text { (individual concentrations) }\end{array}$} \\
\hline Low concentration & 500 & $461 \pm 110$ & $340-760$ \\
\hline High concentration & 1500 & $1315 \pm 252$ & $850-2070$ \\
\hline
\end{tabular}

\section{References}

1. De'ath, G.; Fabricius, K.E.; Sweatman, H.; Puotinen, M. The 27-year decline of coral cover on the Great Barrier Reef and its causes. Proc. Natl. Acad. Sci. USA 2012, 109, 17995-17999. [CrossRef] [PubMed]

2. Birkeland, C. Terrestrial runoff as a cause of outbreaks of Acanthaster planci (Echinodermata: Asteroidea). Mar. Biol. 1982, 69, 175-185. [CrossRef]

3. Brodie, J. From the effects of terrestrial runoff: A review. Mar. Freshw. Res. 1992, 43, 539. [CrossRef]

4. Brodie, J.; Fabricius, K.; De'ath, G.; Okaji, K. Are increased nutrient inputs responsible for more outbreaks of crown-of-thorns starfish? An appraisal of the evidence. Mar. Pollut. Bull. 2005, 51, 266-278. [CrossRef] [PubMed]

5. Devlin, M.J.; Brodie, J. Terrestrial discharge into the Great Barrier Reef Lagoon: Nutrient behavior in coastal waters. Mar. Pollut. Bull. 2005, 51, 9-22. [CrossRef] [PubMed]

6. Fabricius, K.E.; Okaji, K.; De'ath, G. Three lines of evidence to link outbreaks of the crown-of-thorns seastar Acanthaster planci to the release of larval food limitation. Coral Reefs 2010, 29, 593-605. [CrossRef]

7. Lucas, J.S. Quantitative studies of feeding and nutrition during larval development of coral reef asteroid Acanthaster planci (L.). J. Exp. Mar. Biol. Ecol. 1982, 65, 173-193. [CrossRef]

8. Wolfe, K.; Graba-Landry, A.; Dworjanyn, S.A.; Byrne, M. Larval starvation to satiation: Influence of nutrient regime on the success of Acanthaster planci. PLoS ONE 2015, 10, e0122010. [CrossRef] [PubMed]

9. Uthicke, S.; Logan, M.; Liddy, M.; Francis, D.; Hardy, N.; Lamare, M. Climate change as an unexpected co-factor promoting coral eating seastar (Acanthaster planci) outbreaks. Sci. Rep. 2015, 5, 8402. [CrossRef] [PubMed] 
10. Strathmann, R.R. The feeding behavior of planktotrophic echinoderm larvae: Mechanisms, regulation, and rates of suspensionfeeding. J. Exp. Mar. Bio. Ecol. 1971, 6, 109-160. [CrossRef]

11. Strathmann, R.R. Larval Feeding in Echinoderms. Am. Zool. 1975, 15, 717-730. [CrossRef]

12. Ayukai, T. Ingestion of ultraplankton by the planktonic larvae of the crown-of-thorns starfish, Acanthaster planci. Biol. Bull. 1994, 186, 90-100. [CrossRef]

13. Okaji, K.; Ayukai, T.; Lucas, J.S. Selective feeding by larvae of the crown-of-thorns starfish, Acanthaster planci (L.). Coral Reefs 1997, 16, 47-50. [CrossRef]

14. Nakajima, R.; Nakatomi, N.; Kurihara, H.; Fox, M.; Smith, J.; Okaji, K. Crown-of-thorns starfish larvae can feed on organic matter released from corals. Diversity 2016, 8, 18. [CrossRef]

15. Collier, J.L. Flow cytometry and the single cell in phycology. J. Phycol. 2000, 36, 628-644. [CrossRef]

16. Hofstraat, J.W.; van Zeijl, W.J.M.; de Vreeze, M.E.J.; Peeters, J.C.H.; Peperzak, L.; Colijn, F.; Rademaker, T.W.M. Phytoplankton monitoring by flow cytometry. J. Plankton Res. 1994, 16, 1197-1224. [CrossRef]

17. Cowles, T.J.; Olson, R.J.; Chisholm, S.W. Food selection by copepods: Discrimination on the basis of food quality. Mar. Biol. 1988, 100, 41-49. [CrossRef]

18. Baldwin, B.S. Selective particle ingestion by oyster larvae (Crassostrea virginica) feeding on natural seston and cultured algae. Mar. Biol. 1995, 123, 95-107. [CrossRef]

19. Dionisio Pires, L.M.; Jonker, R.R.; Van Donk, E.; Laanbroek, H.J. Selective grazing by adults and larvae of the zebra mussel (Dreissena polymorpha): Application of flow cytometry to natural seston. Freshw. Biol. 2004, 49, 116-126. [CrossRef]

20. Fileman, E.S.; Lindeque, P.K.; Harmer, R.A.; Halsband, C.; Atkinson, A. Feeding rates and prey selectivity of planktonic decapod larvae in the Western English Channel. Mar. Biol. 2014, 161, 2479-2494. [CrossRef]

21. Revelante, N.; Gilmartin, M. Dynamics of phytoplankton in the Great Barrier Reef lagoon. J. Plankton Res. 1982, 4, 47-76. [CrossRef]

22. Devlin, M.J.; Debose, J.; Ajani, P.; Petus, C.; da Silva, E.T.; Brodie, J.O.N. Phytoplankton in the Great Barrier Reef: Microscopy analysis of community structure in high flow events. Report to the National Environmental Research Program. Reef and Rainforest Research Centre Limited: Cairns, Australia, 2013; p. 68.

23. Conlan, J.A.; Jones, P.L.; Turchini, G.M.; Hall, M.R.; Francis, D. Changes in the nutritional composition of captive early-mid stage Panulirus ornatus phyllosoma over ecdysis and larval development. Aquaculture 2014, 434, 159-170. [CrossRef]

24. Angell, A.R.; Mata, L.; de Nys, R.; Paul, N.A. The protein content of seaweeds: A universal nitrogen-to-protein conversion. J. Appl. Phycol. 2016, 28, 511-524. [CrossRef]

25. Bureau, D.P.; Kaushik, S.J.; Cho, C.Y. Bioenergetics. In Fish Nutrition; Halver, J.E., Hardy, R.W., Eds.; Academic Press: San Diego, CA, USA, 2002.

26. Schaffelke, B.; Carleton, J.; Skuza, M.; Zagorskis, I.; Furnas, M.J. Water quality in the inshore Great Barrier Reef lagoon: Implications for long-term monitoring and management. Mar. Pollut. Bull. 2012, 65, 249-260. [CrossRef] [PubMed]

27. Okaji, K. Feeding ecology in the early life stages of the crown-of-thorns starfish, Acanthaster planci (L.). PhD dissertation, James Cook University, Townsville, Australia, 1996.

28. Coughlan, J. The estimation of filtering rate from the clearance of suspensions. Mar. Biol. 1969, 2, 356-358. [CrossRef]

29. Vanderploeg, H.a.; Scavia, D. Calculation and use of selectivity coefficients of feeding: Zooplankton grazing. Ecol. Modell. 1979, 7, 135-149. [CrossRef]

30. Bolker, B.M.; Brooks, M.E.; Clark, C.J.; Geange, S.W.; Poulsen, J.R.; Stevens, M.H.H.; White, J.S.S. Generalized linear mixed models: A practical guide for ecology and evolution. Trends Ecol. Evol. 2009, 24, 127-135. [CrossRef] [PubMed]

31. Marin, V.; Huntley, M.E.; Frost, B. Measuring feeding rates of pelagic herbivores: Analysis of experimental design and methods. Mar. Biol. 1986, 58, 49-58. [CrossRef]

32. Nakagawa, S.; Schielzeth, H. A general and simple method for obtaining R2 from generalized linear mixed-effects models. Meth. Ecol. Evol. 2013, 4, 133-142. [CrossRef]

33. Burnham, K.P.; Anderson, D.R. Model selection and multimodel inference: A practical information theoretic approach, 2nd ed.; Springer: New York, NY, USA, 2002.

34. Burnham, K.P.; Anderson, D.R.; Huyvaert, K.P. AIC model selection and multimodel inference in behavioral ecology: Some background, observations, and comparisons. Behav. Ecol. Sociobiol. 2011, 65, 23-35. [CrossRef] 
35. R Development Core Team. R: A language and environment for statistical computing; R Foundation for Statistical Computing: Vienna, Austria; ISBN: 3-900051-07-0. 2014; Available online: http:/ /www.R-project.org/. (accessed on 21 January 2015).

36. Pratchett, M.S.; Caballes, C.F.; Rivera-Posada, J.A.; Sweatman, H.P. Limits to understanding and managing outbreaks of crown-of-thorns starfish (Acanthaster spp.). Oceanogr. Mar. Biol. 2014, 52, 133-199.

37. Mellin, C.; Lurgi, M.; Matthews, S.; MacNeil, M.A.; Caley, M.J.; Bax, N.; Przeslawski, R.; Fordham, D.A. Forecasting marine invasions under climate change: Biotic interactions and demographic processes matter. Biol. Conserv. 2016. [CrossRef]

38. Pratchett, M.S.; Dworjanyn, S.A.; Mos, B.; Caballes, C.F.; Thompson, C.A.; Blowes, S. Larval survivorship and settlement of crown-of-thorns starfish (Acanthaster cf. solaris) at varying algal cell densities. Diversity 2017, 9, 2. [CrossRef]

39. Hay, M.E. Marine chemical ecology: Chemical signals and cues structure marine populations, communities, and ecosystems. Ann. Rev. Mar. Sci. 2009, 1, 193-212. [CrossRef] [PubMed]

40. Labarbera, M. Feeding currents and particle capture mechanisms in suspension feeding animals. Integr. Comp. Biol. 1984, 24, 71-84. [CrossRef]

41. Rubenstein, D.I.; Koehl, M.A.R. The mechanisms of filter feeding: Some theoretical considerations. Am. Nat. 1977, 111, 981. [CrossRef]

42. Rassoulzadegan, F.; Fenaux, L.; Strathmann, R.R. Effect of flavor and size on selection of food by suspension-feeding plutei. Limnol. Oceanog. 1984, 29, 357-360. [CrossRef]

43. Strathmann, R.R. Time and extent of ciliary response to particles in a non-filtering feeding mechanism. Biol. Bull. 2007, 212, 93-103. [CrossRef] [PubMed]

44. Frost, B.W. Effects of size and concentration of food particles on the feeding behavior of the marine planktonic copepod Calanus pacificus. Limnol. Oceanogr. 1972, 17, 805-815. [CrossRef]

45. Nell, J.A.; Connor, W.A.O. The evaluation of fresh algae and stored algal concentrates as a food source for Sydney rock oyster, Succostrea commercialis (Iredale \& Roughley), larvae. Aquaculture 1991, 99, 277-284.

46. Delaunay, F. The effect of monospecific algal diets on growth and fatty acid composition of Pecten maximus (L.) larvae. J. Exp. Mar. Bio. Ecol. 1993, 173, 163-179. [CrossRef]

47. Ponis, E.; Robert, R.; Parisi, G.; Tredici, M. Assessment of the performance of Pacific oyster (Crassostrea gigas) larvae fed with fresh and preserved Pavlova lutheri concentrates. Aquaculture Inter. 2003, 11, 69-79. [CrossRef]

48. Byrne, M.; Sewell, M.A.; Prowse, T.A.A. Nutritional ecology of sea urchin larvae: Influence of endogenous and exogenous nutrition on echinopluteal growth and phenotypic plasticity in Tripneustes gratilla. Funct. Ecol. 2008, 22, 643-648. [CrossRef]

49. Duy, N.D.Q.; Francis, D.S.; Pirozzi, I.; Southgate, P.C. Use of micro-algae concentrates for hatchery culture of sandfish, Holothuria scabra. Aquaculture 2016, 464, 145-152. [CrossRef]

50. Suzuki, G.; Yasuda, N.; Ikehara, K.; Fukuoka, K.; Kameda, T.; Kai, S.; Nagai, S.; Watanabe, A.; Nakamura, T.; Kitazawa, S.; et al. Detection of a high-density brachiolaria-stage larval population of Crown-of-Thorns sea star (Acanthaster planci) in Sekisei lagoon (Okinawa, Japan). Diversity 2016, 8, 9. [CrossRef]

(C) 2017 by the authors; licensee MDPI, Basel, Switzerland. This article is an open access article distributed under the terms and conditions of the Creative Commons Attribution (CC BY) license (http:/ / creativecommons.org/licenses/by/4.0/). 